Aerodynamic Design Criteria for Class 8 Heavy Vehicles Trailer Base Devices to Attain Optimum Performance

K. Salari, J. Ortega

December 20, 2010 
This document was prepared as an account of work sponsored by an agency of the United States government. Neither the United States government nor Lawrence Livermore National Security, LLC, nor any of their employees makes any warranty, expressed or implied, or assumes any legal liability or responsibility for the accuracy, completeness, or usefulness of any information, apparatus, product, or process disclosed, or represents that its use would not infringe privately owned rights. Reference herein to any specific commercial product, process, or service by trade name, trademark, manufacturer, or otherwise does not necessarily constitute or imply its endorsement, recommendation, or favoring by the United States government or Lawrence Livermore National Security, LLC. The views and opinions of authors expressed herein do not necessarily state or reflect those of the United States government or Lawrence Livermore National Security, LLC, and shall not be used for advertising or product endorsement purposes.

This work performed under the auspices of the U.S. Department of Energy by Lawrence Livermore National Laboratory under Contract DE-AC52-07NA27344. 


\title{
Aerodynamic Design Criteria for Class 8 Heavy Vehicles Trailer Base Devices to Attain Optimum Performance
}

\author{
Kambiz Salari and Jason Ortega \\ salari1@IInl.gov \\ Lawrence Livermore National Laboratory, Livermore CA
}

Lawrence Livermore National Laboratory (LLNL) as part of its Department of Energy (DOE), Energy Efficiency and Renewable Energy (EERE), and Vehicle Technologies Program (VTP) effort has investigated class 8 tractor-trailer aerodynamics for many years. This effort has identified many drag producing flow structures around the heavy vehicles and also has designed and tested many new active and passive drag reduction techniques and concepts for significant on the road fuel economy improvements. As part of this effort a database of experimental, computational, and conceptual design for aerodynamic drag reduction devices has been established.

The objective of this report is to provide design guidance for trailer base devices to improve their aerodynamic performance. These devices are commonly referred to as boattails, base flaps, tail devices, and etc. The information provided here is based on past research and our most recent full-scale experimental investigations in collaboration with Navistar Inc. Additional supporting data from LLNL/Navistar wind tunnel, track test, and on the road test will be published soon.

The trailer base devices can be identified by 4 flat panels that are attached to the rear edges of the trailer base to form a closed cavity. These devices have been engineered in many different forms such as, inflatable and non-inflatable, 3 and 4-sided, closed and open cavity, and etc. The following is an indepth discussion with some recommendations, based on existing data and current research activities, of changes that could be made to these devices to improve their aerodynamic performance.

There are 6 primary factors that could influence the aerodynamic performance of trailer base devices:

1. Deflection angle

2. Boattail length

3. Sealing of edges and corners

4. 3 versus 4 -sided

o Position of the $4^{\text {th }}$ plate

5. Boattail vertical extension

o Skirt - boattail transition

6. Closed versus open cavity

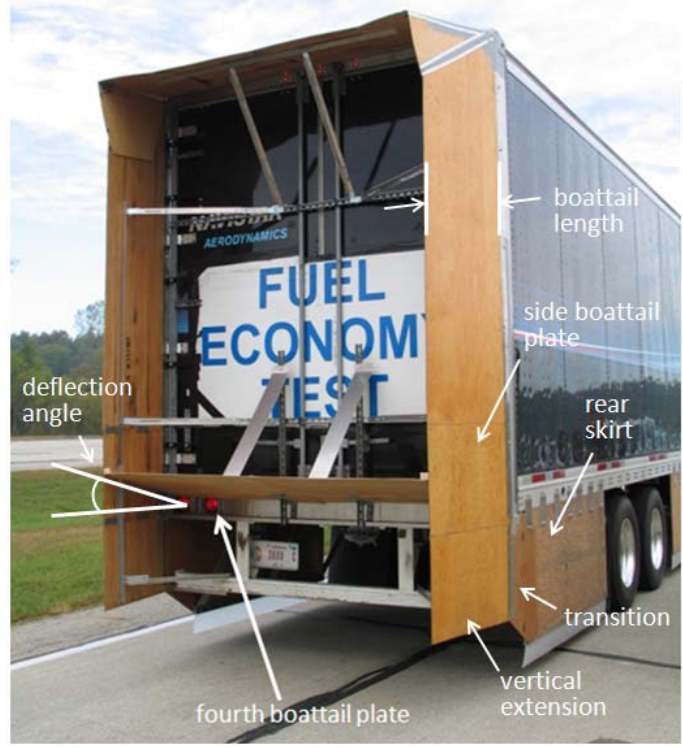




\section{Recommended deflection angle: 11-15 degrees, depending on the upstream flow quality}

a. Many different researchers have found the following optimum deflection angles:

i. Cooper (1985, 2003): $15 \pm$ ? degrees, 3-sided boattail, full and scale wind tunnel test and road test, not clear if this optimum angle was determined with other devices installed

ii. Browand, et al. (2005): $13 \pm$ ? degrees, 3-sided boattail, full scale track test, no tractor roof fairing, no gap fairing, no trailer skirts

iii. Grover \& Visser (2006): $15 \pm$ ? degrees sides and top, 7 degrees bottom, full scale road test, no gap fairing, no trailer skirts

iv. Schoon \& Pan (2007): 12.5 \pm ? degrees, 4-sided boattail, scale wind tunnel test

v. LLNL/Navistar NASA NFAC Full Scale Test (2010): $11 \pm 2$ degrees, full scale wind tunnel test, reduced tractor-trailer gap size, trailer skirts

It should be noted that none of these studies have measured the impact of the boattail length upon the optimum deflection angle. Experiments should be conducted to obtain such a correlation. The observed variation in the angle can potentially be attributed to the upstream flow quality, which depends upon the aerodynamic treatment of the tractor, tractor-trailer gap, and trailer underbody. This effect was observed in the studies of DOE/LLNL/NASA/Storms, et al. (2006) and LLNL/Navistar NASA NFAC Full Scale Test (2010). In DOE/LLNL/NASA/Storms, et al. (2006), the optimum angle increased to 20 degrees which we speculate was due to both the GCM being a more aerodynamic tractor and also, the 12 foot pressure wind tunnel having a very clean flow.

\section{References}

Cooper, K.R., The Effect of Front-Edge Rounding and Rear-Edge Shaping on the Aerodynamic Drag of Bluff Bodies in Ground Proximity, SAE Paper 850288, 1985.

Cooper, K.R., Truck Aerodynamics Reborn-Lessons from the Past, SAE Paper 2003-01-3376, 2003.

Browand, F., Radovich, C., Boivin, M., Fuel Savings by Means of Flaps Attached to the Base of a Trailer: Field Test Results, SAE Paper 2005-01-1016, 2005.

Grover, K. and Visser, K.D., Over-the-Road Tests of Sealed Aft Cavities on Tractor Trailers, SAE Paper 2006-01-3529, 2006.

Storms, B.L., et al., A Summary of the Experimental Results for a Generic Tractor-Trailer in the Ames Research Center 7- by 10-Foot and 12-Foot Wind Tunnels, NASA/TM-2006-213489, 2006. Schoon, R., Pan, F.P., Practical Devices for Heavy Truck Aerodynamic Drag Reduction, SAE Paper 2007-01-1781, 2007. 


\section{Recommended boattail length: $24 "-32 "$}

In our recent research, we have not observed measureable improvement in performance when the boattail length is increased from 32" to 48". Cooper (2003) has tested shorter length boattails and found the optimum length to be about 24". Croll, et al. (1996) has shown that there is an aerodynamic benefit to extending the boattail length up to $96 "$. However, due to DOT regulations and operational constraints, this long of a boattail is not recommended. In addition, the boattail performance can be impacted by the upstream flow quality, which depends upon the presence of gap devices and the tractor-trailer gap size, tractor aerodynamic treatments, and trailer underbody devices.

References

Cooper, K.R., Truck Aerodynamics Reborn-Lessons from the Past, SAE Paper 2003-01-3376, 2003.

Croll, R.H., et al., Experimental Investigation of the Ground Transportation System (GTS) Project for Heavy Vehicle Drag Reduction, SAE Paper 960907, 1996.

\section{Recommendation of sealing of edges and corners}

The aerodynamic performance of the boattail is dependent upon proper sealing of the corner edges of the vertical and horizontal plates. In addition, the edges of the boattail that join to the trailer must be sealed and not protrude out into the freestream flow.

\section{Recommendation on the number of boattail plates: $\mathbf{3}$ versus 4-sided boattail, position of the fourth plate}

We have inconclusive data from both the full-scale wind tunnel and track tests on the aerodynamic benefits of the fourth boattail plate. In the full-scale wind tunnel test, we observed a slight improvement in the boattail performance when the fourth plate was removed, but this change was within the experimental uncertainty. In the track test, removal of the fourth plate produced a change in the performance that was also within the experimental uncertainty. The same result was observed when the vertical position of the fourth plate was changed between two positions. In summary, the boattail performance was not sensitive to the presence of the fourth plate, which is in contrast to the findings of Cooper (2003), who showed that the fourth plate made a contribution to the overall performance of the boattail. We propose that additional research be conducted to address this question of the fourth boattail plate and its location. Hence, no recommendation can be made at the present time.

References

Cooper, K.R., Truck Aerodynamics Reborn-Lessons from the Past, SAE Paper 2003-01-3376, 2003. 


\section{Recommendation of the boattail vertical extension and the transition to the rear trailer skirt}

Lanser, et al. (1991) and Cooper (2003) included rear trailer skirts in their wind tunnel study, but only Cooper explored the benefits of these skirts and their transition to the trailer boattail device and showed that they provided additional drag reduction. In our recent experiment, we observed improvements in drag reduction when the rear trailer skirts were installed and blended into the boattail. We propose that the rear trailer skirts be further investigated with a boattail that has vertical extensions.

References

Cooper, K.R., Truck Aerodynamics Reborn-Lessons from the Past, SAE Paper 2003-01-3376, 2003. Lanser, W.R., Ross, J.C., Kaufman, A.E., Aerodynamic Performance of a Drag Reduction Device on a Full-Scale Tractor/Trailer, SAE Paper 912125, 1991.

\section{Recommendation of closed versus open cavity}

Based on low-Reynolds number experimental testing, the open cavity provides a benefit by positioning the trailer base at a distance from the large vortices that roll up from the edges of the boattail plates. This allows the low pressure region of the vortex core to be shifted away from the trailer base. However, at higher Reynolds number, the flow structures are much smaller and the same trend may not hold. Currently at full-scale Reynolds number, there is not enough conclusive data for heavy vehicle geometries to suggest whether there are benefits to opening or closing the trailer base cavity.

\section{Recommendation for boattail application of drop-frame versus straight-frame trailer}

A typical straight-frame trailer boattail device is designed to increase the pressure on the trailer base area and hence reduce the aerodynamic drag. For the drop-frame trailers this area is larger and the boattail side panels should be extended to cover this additional area. The aerodynamic benefit is apparent since the elevated pressure is now applied on a larger surface area which translates to enhanced drag reduction. Such a boattail device for a drop-frame trailer is shown here.

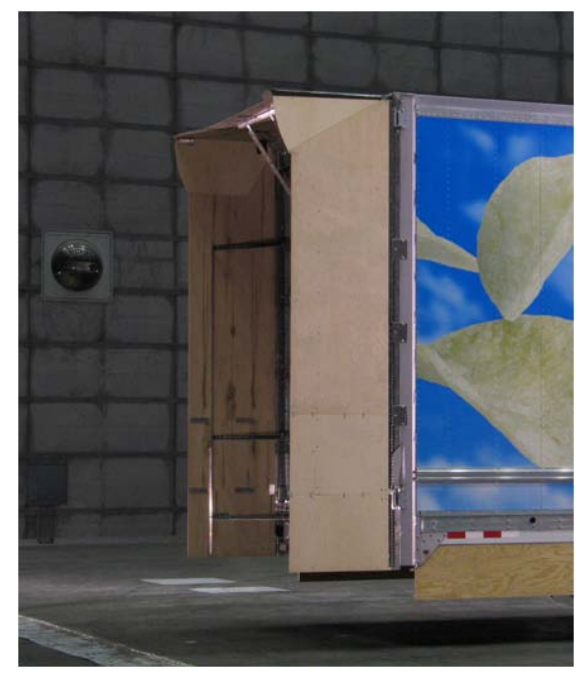

